\title{
Toward an Understanding of the Evolution of IFIP WG 8.6 Research
} \author{
David G. Wastell ${ }^{5}$, and Deborah Bunker ${ }^{6}$ \\ ${ }^{1}$ School of Business \& Economics, \\ Swansea University, \\ Swansea, United Kingdom \\ ${ }^{2}$ Software Engineering Institute, \\ Carnegie Mellon University, \\ Pittsburgh, Pennsylvania, U.S.A. \\ ${ }^{3}$ School of Business \& Economics, \\ Swansea University, \\ Swansea, United Kingdom \\ ${ }^{4}$ School of Business Information Technology, \\ RMIT University, \\ Melbourne, Australia \\ ${ }^{5}$ Nottingham University Business School, \\ Nottingham, United Kingdom \\ ${ }^{6}$ Faculty of Economics and Business, \\ University of Sydney, \\ Sydney, NSW, Australia
}

Yogesh K. Dwivedi ${ }^{1}$, Linda Levine ${ }^{2}$, Michael D. Williams ${ }^{3}$, Mohini Singh ${ }^{4}$,

\begin{abstract}
This article analyses research published in the previous 11 IFIP TC8 WG 8.6 conferences held between 1993 and 2008. Analysis of the published material includes examining variables such as most active authors, citation analysis, universities associated with the most publications, geographic diversity, and authors' backgrounds. The keyword analysis suggests that IFIP WG 8.6 research has evolved from examining basic issues such as organizational impact of technology adoption and technology transfer to contemporary issues such as open innovation. We suggest this research has implications for researchers, conference organizers, and research institutions.
\end{abstract}

Keywords: Adoption, diffusion, IFIP TC8 WG 8.6, IS research, profile.

\section{Introduction}

Information systems/information technology adoption and diffusion research is considered to be among the more mature areas of exploration within the IS discipline (Dwivedi, Williams, and Lal 2008). Such research has been published in a range of IS journals (Dwivedi, Williams, and Lal 2008; Williams et al. 2009) and has appeared in the proceedings of numerous IS conferences. Apart from these generic outlets for 
publishing research in the area, there are also some specialized fora devoted to the discussion and publication of adoption and diffusion research. In this category, IFIP WG 8.6 is considered a prime venue and publishing outlet for researchers focusing on the adoption and diffusion of IS/IT. Since its inception in 1993 in Pittsburgh, Pennsylvnia, IFIP WG 8.6 has taken place in a number of venues in North America, Europe, and the Asia-Pacific region. During its 16 years of existence, it has evolved across a number of dimensions, including research topics addressed and the community of researchers who participate and contribute.

In order to understand the multidimensional evolution occurring between the Pittsburgh and Madrid events, it is useful to analyze the publications appearing in the various proceedings in order to examine if any trends exist. Bearing in mind the potential usefulness of such an analysis for both audience and editorial/organizing teams, similar efforts have been made to analyze well established conferences such as the European Conference on Information Systems (ECIS) (Whitley and Galliers 2007), and numerous IS journals including the European Journal of Information Systems (EJIS) (Dwivedi and Kuljis 2008), Information \& Management (I\&M) (Palvia et al. 2007), Information Systems Frontiers (Dwivedi et al. 2009), Information Systems Journal (ISJ) (Avison et al. 2008), and Journal of Electronic Commerce Research (JECR) (Dwivedi, Kiang et al. 2008).

The aim of this paper is to provide a systematic review of the literature pertaining to IS/IT adoption and diffusion research published in the proceedings of the IFIP WG 8.6 conferences. This overall aim is realized by means of the following three objectives: (1) to identify and determine the various demographic variables (such as most active authors, institutions, countries, number of coauthors, etc.) associated with IFIP WG 8.6 publications; (2) to undertake citation analysis to analyze the perceived impact of published studies and authors; and (3) to undertake keyword analysis to identify the most frequently examined issues.

The analysis presented in this study offers several contributions. The findings of such an analysis can be used as a basis for comparison (Whitley and Galliers 2007) with other outlets. For instance, the findings of this study can be used as the basis for comparison with other groups focusing on diffusion research (such as DIGIT), and with adoption and diffusion research published in IS journals and conferences. This can assist with overall trend analysis in order to observe changes in focal, theoretical, and methodological practices prevalent in IS/IT diffusion research. There are several benefits to be associated with the analysis of demographic variables (such as most active authors, institutions, countries, number of coauthors, etc.), particularly as such findings can provide readers with ideas for formal and informal collaboration or assistance. The "most active author" list can also provide editors, associate editors, and conference organizers with ideas for potential reviewers and groups where they can target calls for papers for publishing such research. Similarly, exploring geographical disparity may help in determining suitable venues for future conferences and for creating and sustaining improved regional and continental balance within the IFIP WG 8.6 research community. Finally, keyword analysis can provide new researchers with useful indications as to potentially fruitful topics for examination, and expert and more experienced researchers with an overview of the changing nature of research focus, and methods and theories employed in order to assist with the making of relevant and timely decisions within their own work. 
In order to realize the above objectives, a systematic review of 271 articles appearing in the proceedings of the 11 IFIP WG 8.6 conferences (see Table 1) during the period 1993-2008 was conducted. The remainder of this paper is structured as follows. In section 2 we provide a brief account on origin and evolution of IFIP WG 8.6, followed in section 3 by a discussion of the method employed in the analysis. Our findings are presented and discussed in section 4, and finally, section 5 presents conclusions from this work and the limitations of our approach.

\section{Background: The Origin and Evolution of IFIP WG 8.6}

In 1991, Priscilla Fowler and Linda Levine, both of the Software Engineering Institute (SEI) at Carnegie Mellon University (CMU), became engaged in dialogue with two SEI senior staff members about IFIP, its role, technical committees, and how IFIP accomplished its work through working groups. These conversations were with Len Bass and Mario Barbacci, both of whom were active in IFIP, specifically with TC 2 on Software. Both Fowler and Levine were working on an SEI research and development project on technology transfer and diffusion of innovations, and Bass and Barbacci duly encouraged them to propose a new IFIP working group in this area. At that time, Fowler and Levine were committed to attend and present a paper at the upcoming IFIP World Congress in Madrid, and so they considered how to approach this challenge, and to explore the possibilities and make contact with potential sponsors at the event. Fowler and Levine then identified several stakeholders. First, they discovered that Brian Oakley (Logica) was presenting a workshop on cooperative $\mathrm{R} \& \mathrm{D}$, and so they sent an advance e-mail to make contact, highlight shared interests, and arranged to attend Oakley's session and meet. Second, they identified two technical committees where a proposed group on Diffusion and Transfer might be of interest-TC2 (Software) and TC8 (Information Systems) - and sent advance e-mails to communicate their interest and request meetings with the respective TC chairs, Peter Poole and Gordon Davis. At the Madrid IFIP World Congress, they met with both Poole and Davis. In the case of TC8, they were invited to a working meeting to discuss their proposal for a new WG on Diffusion, Transfer, and Implementation of Information Technology. The discussion was lively and energetic, exploring shared interests, the overlap with WG 8.2 (Information Systems and Organizations), and how a new WG on diffusion might bring more practitioners to the largely academic IFIP forum. This was in keeping with the SEI's mission of improving the state of the practice of software engineering. It eventually became apparent that TC8 was a better match for the proposal than TC2, and Fowler and Levine duly received approval to hold a working conference that would ideally, demonstrate interest in this area. If the conference was successful in demonstrating interest in, and the importance of, the subject area, then IFIP would consider supporting the establishment of a new working group. This process is typically how IFIP formally charters its new groups.

Over the following 18 months, an IFIP working conference was planned on Diffusion, Transfer, \& Implementation of Information Technology, in cooperation with the SEI and the IEEE Computer Society Committee on Software Engineering. This event was held on October 10-13, 1993, at Champion, PA, in the area also referred to 
as Seven Springs. The event was very successful, attracting over 120 academics and practitioners from around the globe. Gordon Davis welcomed the attendees and Priscilla Fowler (Program Chair) opened the event. Three presentation tracks ran concurrently throughout; however, the format was atypical in allowing for afternoon outdoor activity: scheduled breaks were held from 3:30 p.m. to 6:00 p.m. so participants might admire the fall foliage, followed by dinner, and then six working sessions were held on both evenings. Keynotes were given by-Larry Lien (Training and Operations, US), Bernard Glasson (Curtin University, AU), and Rainer Zimmerman (ESSI, EU). All attendees received a conference binder with all submissions. However, the proceedings (see Levine 1994) were distributed some time after the event, early the following year, in order that written summaries of the working group sessions could be included. Shortly afterward, in 1994, the new IFIP WG 8.6 on Diffusion, Transfer, and Implementation was chartered by Technical Committee 8 and the IFIP General Assembly.

The first official working conference on Diffusion and Adoption of Information Technology was held October 14-17, 1995, at Leangkollen, Oslo, Norway, organized by Karlheinz Kautz, Jan Pries-Heje, Tor J Larsen, and Pal Sorgaard. The first Working Group 8.6 Chair was Priscilla Fowler, who served just short of two terms. She was followed by Karlheinz Kautz, who also served two terms. Kautz was followed by Linda Levine, currently serving her first term as Chair. The current website for the group, with additional history on past events, is available at http://www.ifipwg86.org/.

\section{Research Method}

In order to create a profile of the most active authors, universities, and countries, the study thoroughly examined all papers appearing in proceedings of IFIP WG 8.6 conferences held between 1993 and 2008. The authors reviewed a total of 271 published papers (see Table 1 for a breakdown of numbers of papers from different conferences) in order to capture data on these variables. Such an approach for the systematic classification of research published in a particular journal or conference is termed a meta-study or longitudinal literature review (Palvia et al. 2007; Dwivedi et al. 2009; Dwivedi, Williams, and Lal 2008). Since this approach has been successfully employed previously to profile a number of IS and related journals (Avison et al. 2008; Dwivedi, Kiang et al. 2008; Dwivedi and Kuljis 2008; Dwivedi et al. 2009; Palvia et al. 2007), we also utilized it to profile IFIP WG8.6 conference publications.

Various items were recorded for each article including the citations of selected articles, geographic regions, authors' backgrounds, and the keywords used by the authors. The impact of the research was assessed using Google Scholar citation counts. Institutional contributions/productivity were examined by utilizing normal count approach in which one count was allocated to each authors even if they were from the same institution. Both the authors' backgrounds and geographic location variables were adapted from previous studies (Avison et al. 2008; Dwivedi, Kiang et al. 2008; Dwivedi et al. 2009). It is important to emphasize at this point that, like previous profiling studies (Palvia et al. 2007), the findings of this study, in terms of universities with the most contributors and authors with the most publications, should be regarded as indicative and not an authoritative declaration. 


\section{Findings and Discussion}

\subsection{Most Active Authors}

An analysis is conducted to identify those authors who published the most in previous IFIP 8.6 (1993-2008) conferences. For presenting the findings of this study, only those authors who have published three or more articles during the period studied are included in the list. A total of 429 authors contributed to the 271 articles. Table 2 lists the 30 most active authors, ordered according to the number of articles published in IFIP 8.6 conferences. The findings show that the largest number of contributions by any author was 15 , followed by two authors contributing 10 publications each. A further five authors contributed seven articles, then two authors with six publications each. All of the most active authors and their associated number of publications are listed in Table 2. Although not listed in the table, 45 authors contributed to two articles each and, finally, the largest number of authors $(\mathrm{C}=354)$ contributed to one article each.

Table 1. List of IFIP WG8.6 Conferences and Number of Papers Analyzed

\begin{tabular}{|c|l|c|c|}
\hline SN & \multicolumn{1}{|c|}{ Conference } & Year & \# of Papers \\
\hline 1 & Pittsburgh, USA & 1993 & 30 \\
\hline 2 & Oslo, Norway & 1995 & 14 \\
\hline 3 & Ambleside, UK & 1997 & 22 \\
\hline 4 & Helsinki, Finland & 1998 & 36 \\
\hline 5 & Banff, Canada & 2001 & 18 \\
\hline 6 & Sydney, Australia & 2002 & 13 \\
\hline 7 & Copenhagen, Denmark & 2003 & 15 \\
\hline 8 & Atlanta, USA & 2005 & 24 \\
\hline 9 & Galway, Ireland & 2006 & 22 \\
\hline 10 & Manchester, UK & 2007 & 44 \\
\hline 11 & Madrid, Spain & & 33 \\
\hline Total Number of Papers Analyzed & $\mathbf{2 7 1}$ \\
\hline
\end{tabular}

In terms of active authors, it is interesting to correlate publishing behaviors across publishing outlets. For this purpose, we compared outputs in IFIP WG8.6 proceedings with a previous profiling study of authors disseminating adoption and diffusion research in various outlets (Dwivedi, Williams, and Lal 2008). Interestingly, only a small number of authors (Damsgaard, Lyytinen, Pries-Heje, Fichman, and Dwivedi), appear in both studies. This neatly indicates that different publication outlets have their specific author populations for contributing scholarly articles. While the overall author population is large, the dominant behavior is of loyal authors who prefer to concentrate on specific outlets. We surmise that such authors understand the editorial policy, quality criteria, and review process of their preferred outlet well enough that they manage to publish more than two or three articles in the same outlet (Dwivedi et al. 2009; Palvia et al. 2007). In conferences, researchers may have developed a 
Table 2. The Most Active Authors

\begin{tabular}{|l|c|l|l|}
\hline \multicolumn{1}{|c|}{ Author } & \# of Papers & \multicolumn{1}{c|}{ Author } & \# of Papers \\
\hline Kautz, K. & 15 & Leon, G. & 4 \\
\hline McMaster, T. & 10 & Swanson, E. B. & 4 \\
\hline Pries-Heje, J. & 10 & Zmud, R. W. & 4 \\
\hline Wastell, D. G. & 9 & Baskerville, R. L. & 3 \\
\hline Levine, L. & 8 & Costello, G. J. & 3 \\
\hline Damsgaard, J. & 7 & Donnellan, B. & 3 \\
\hline Fitzgerald, B. & 7 & Dwivedi, Y. K. & 3 \\
\hline Lyytinen, K. & 7 & Feller, J. & 3 \\
\hline Larsen, T. J. & 6 & Fichman, R. G. & 3 \\
\hline Mathiassen, L. & 6 & Fowler, P. & 3 \\
\hline Bunker, D. & 5 & Ginn, M. L. & 3 \\
\hline Borjesson, A. & 4 & Nielsen, P. A. & 3 \\
\hline Chiasson, M. W. & 4 & Sambamurthy, V. & 3 \\
\hline Finnegan, P. & 4 & Sauer, C. & 3 \\
\hline Henriksen, H. Z. & 4 & Vidgen, R. T. & 3 \\
\hline
\end{tabular}

social network among a community of academics and scholars with whom they wish and prefer to share their ideas, thoughts, and findings.

\subsection{Gender of Authors}

Gender information of a total of 548 contributors was extracted from authors' biographies; however, it was not possible to determine the gender of 50 authors due to a lack of such information in their biographies or due to complete lack of biography in certain articles. The analysis presented in Table 3 suggests that the proportion of male authors is much higher than females. A total of 416 (69.56 percent) male authors contributed articles in IFIP 8.6. A much lower proportion of female authors (22.07 percent) made intellectual contributions to the proceedings. Table 3 also presents the trend of gender proportion from 1993 to 2008, which suggests that female contributors' proportion varies between 11.8 percent and 31.4 percent and male authors' proportion varies between 68.6 percent and 88.2 percent. This suggests that the gender proportion is slightly skewed toward the male side.

\subsection{Occupation of Authors}

The data presented in Table 4 suggests that the highest proportion of IFIP 8.6 authors hold professorship positions. An almost equal number of authors were practitioners in various roles. This is then followed by lecturer (10.54 percent) and doctoral candidates (9.70 percent). Other categories are listed in Table 4. For 122 authors, it was not possible to determine their position or job roles from the biography provided with the paper. 


\subsection{Background of Authors: Academia Versus Industry}

Table 5 illustrates the number of authors/contributors from academia or industry. The largest number of contributors were from academia (85.3 percent) and a comparatively small proportion of authors were based in industry (13.4 percent) and the public sector (1.3 percent) (Table 5).

Table 3. Gender of Authors

\begin{tabular}{|l|c|c|c|c|c|}
\hline \multirow{2}{*}{ Year } & \multicolumn{2}{|c|}{ Female } & \multicolumn{2}{c|}{ Male } & \multirow{2}{*}{ Total } \\
\cline { 2 - 5 } & Count & $\mathbf{\%}$ & Count & \% & 34 \\
\hline 1993 & 4 & 11.8 & 30 & 88.2 & 26 \\
\hline 1995 & 8 & 30.8 & 18 & 69.2 & 48 \\
\hline 1997 & 12 & 25.0 & 36 & 75.0 & 72 \\
\hline 1998 & 18 & 25.0 & 54 & 75.0 & 17 \\
\hline 2001 & 5 & 29.4 & 12 & 70.6 & 19 \\
\hline 2002 & 3 & 15.8 & 16 & 84.2 & 36 \\
\hline 2003 & 7 & 19.4 & 29 & 80.6 & 61 \\
\hline 2005 & 9 & 14.8 & 52 & 85.2 & 52 \\
\hline 2006 & 12 & 23.1 & 40 & 76.9 & 105 \\
\hline 2007 & 33 & 31.4 & 72 & 68.6 & 78 \\
\hline 2008 & 21 & 26.9 & 57 & 73.1 & $\mathbf{5 4 8}$ \\
\hline Total & $\mathbf{1 3 2}$ & $\mathbf{2 2 . 0 7}$ & $\mathbf{4 1 6}$ & $\mathbf{6 9 . 5 6}$ & \\
\hline
\end{tabular}

Table 4. Occupation of Authors

\begin{tabular}{|l|c|c|}
\hline \multicolumn{1}{|c|}{ Position/Job Role } & Count & \% \\
\hline Professor & 81 & 13.55 \\
\hline Practitioner & 80 & 13.38 \\
\hline Lecturer & 63 & 10.54 \\
\hline PhD Candidate & 58 & 9.70 \\
\hline Associate Professor & 44 & 7.36 \\
\hline Other Research Staff & 42 & 7.02 \\
\hline Senior Lecturer & 35 & 5.85 \\
\hline Assistant Professor & 24 & 4.01 \\
\hline Head/Chair & 22 & 3.68 \\
\hline Public Sector Employee & 8 & 1.34 \\
\hline Member of the Technical Staff & 8 & 1.34 \\
\hline Scientist & 7 & 1.17 \\
\hline Reader & 4 & 0.67 \\
\hline Total & $\mathbf{4 7 6}$ & $\mathbf{7 9 . 6 0}$ \\
\hline Not Known & 122 & 20.40 \\
\hline Total & $\mathbf{5 9 8}$ & $\mathbf{1 0 0 . 0 0}$ \\
\hline
\end{tabular}


Table 5. Authors' Background

\begin{tabular}{|l|c|c|}
\hline \multicolumn{1}{|c|}{ Background } & Count & \% \\
\hline Academic & 510 & 85.3 \\
\hline Industry & 80 & 13.4 \\
\hline Public Sector & 8 & 1.3 \\
\hline Total & $\mathbf{5 9 8}$ & $\mathbf{1 0 0 . 0 0}$ \\
\hline
\end{tabular}

\subsection{Coauthor Analysis}

In terms of the number of coauthors who contributed to each article, 32.1 percent of the articles were written by one author. Articles produced by multiple authors form the following categories: 35.1 percent of articles were coauthored by two authors, forming the largest category, 21.8 percent of articles were by three authors, 5.9 percent of articles were by four authors, 3.3 percent of articles were by five authors, three articles were coauthored by six authors, one article was coauthored by seven authors, and another one by ten authors each (see Table 6).

\subsection{Leading Research Universities}

Authors/contributors from 210 organizations/universities contributed to one or more articles in IFIP 8.6 proceedings between 1993 and 2008. Table 7 presents the top 30 universities having four or more contributors that participated and published IFIP 8.6 conference proceedings. The following is a breakdown of the frequency of contributors/ authors affiliated with a particular organization or university. Copenhagen Business School is ranked first, with a total of 31 contributors. This is followed by two universities with 22 contributors each (Manchester and Salford), and then Carnegie Mellon University with 19 and Georgia State University with 17 contributors. A large number of organizations/universities that are not listed in the table, including 12 universities with four contributors each, 26 organizations/universities with three contributors each, followed by 28 organizations/universities with two contributors each. Finally, the remaining organizations/universities from (210) had affiliations with one contributor from each.

Table 6. Coauthor Analysis

\begin{tabular}{|l|c|c|}
\hline Coauthor & Count & \% \\
\hline 2 & 95 & 35.1 \\
\hline 1 & 87 & 32.1 \\
\hline 3 & 59 & 21.8 \\
\hline 4 & 16 & 5.9 \\
\hline 5 & 9 & 3.3 \\
\hline 6 & 3 & 1.1 \\
\hline 7 & 1 & 0.4 \\
\hline 10 & 1 & 0.4 \\
\hline Total & $\mathbf{2 7 1}$ & $\mathbf{1 0 0 . 0}$ \\
\hline
\end{tabular}


Table 7. Top 30 Universities (With Five or More Contributors)

\begin{tabular}{|l|c|l|c|}
\hline \multicolumn{1}{|c|}{ University } & Count & \multicolumn{1}{c|}{ University } & Count \\
\hline Copenhagen Business School & 31 & Norwegian Computing Centre & 6 \\
\hline University of Manchester & 22 & Norwegian School of Management & 6 \\
\hline University of Salford & 22 & Nottingham University & 6 \\
\hline Carnegie Mellon University & 19 & Technical University of Madrid & 6 \\
\hline Georgia State University & 17 & $\begin{array}{l}\text { University of California at Los } \\
\text { Angeles }\end{array}$ & 6 \\
\hline Aalborg University & 14 & Brunel University & 5 \\
\hline University of Lancaster & 14 & Erasmus University & 5 \\
\hline University College Cork & 13 & Hong Kong Polytechnic & 5 \\
\hline $\begin{array}{l}\text { National University of } \\
\text { Singapore }\end{array}$ & 12 & IT University of Copenhagen & 5 \\
\hline University of New South Wales & 12 & Liverpool University & 5 \\
\hline University of Limerick & 10 & Macquarie University & 5 \\
\hline Ericsson AB & 9 & Swansea University & 5 \\
\hline National University of Ireland & 9 & University of Oslo & 5 \\
\hline University of Jyvaskyla & 8 & University of Turku & 5 \\
\hline University of Wollongong & 7 & University of Warwick & 5 \\
\hline
\end{tabular}

An observation similar to the most active authors has been made in terms of most active institutions. Only a limited number of institutions appear both in the previous list (Dwivedi, Williams, and Lal 2008) and in this research, including Carnegie Mellon University from North America, National University of Singapore from Asia, and Brunel University from Europe. This supports the argument provided in the methodology section that the findings of such studies in terms of institutional productivity should be regarded as indicative and not an authoritative declaration.

\subsection{Country and Geographical Regions}

A total of 26 countries had authors that published in IFIP 8.6 between the years 1993 and 2008 (Table 8). In terms of the number of authors/contributors from different countries, the largest number of contributors were located in the United States (20.7 percent), closely followed by the United Kingdom (20.5 percent). The third largest category (10.3 percent) was formed by Danish authors, with Australia (9.8 percent) in fourth place. Table 8 illustrates the proportion of contributors from the 26 countries.

In terms of the number of authors from different geographical regions (as per the Association of Information Systems, the largest number of authors were from the AIS Region 2 (Europe, Middle East, and Africa) with Europe and the United Kingdom providing 61.6 percent of the authors, followed by the AIS Region 1 (North, Central, and South America) with the United States and Canada providing 21.5 percent of authors. The third largest category was formed by the AIS Region 3 (Asia and the Pacific Rim), with Australia and New Zealand providing 10.6 percent of the authors, followed by South Korea, Singapore, Hong Kong, Taiwan, China, Japan, and India (also in AIS Region 3) providing 5.2 percent of the authors (Table 9). 
Avison et al.'s (2008) research review ISJ, Dwivedi, Kiang et al.'s (2008b) review of JECR, and Dwivedi et al.'s (2009) review of ISF show that a number of geographical regions (such as South America, the Middle East, the former Soviet Union, and many underdeveloped countries of Asia) are under-represented in terms of undertaking and publishing information systems and electronic commerce research. This investigation also reveals highly under-represented levels of adoption and diffusion research from AIS Region 1 (South and Central America) and no representation from a large sector of AIS Region 3 (countries such as Afghanistan, Bangladesh, Cambodia, Indonesia, Malaysia, Nepal, Pakistan, Sri Lanka, and Thailand) (see Tables 8 and 9). This highly unbalanced picture certainly raises an important research agenda for both IS researchers and for researchers from the adoption and diffusion community to investigate: Is this situation a consequence of a global IS digital divide, or is it is due to a lack of interest or lack of necessary expertise and facilities to undertake IS research within such countries? Since such a geographical imbalance is reported in many studies, it deserves academic attention to form a suitable strategy and effort to reduce it.

Table 8. Contributors' Geographical Location

\begin{tabular}{|l|c|l|l|c|c|}
\hline \multicolumn{1}{|c|}{ Country } & Count & \multicolumn{1}{c|}{ Country } & Count & \% \\
\hline USA & 123 & 20.7 & The Netherlands & 6 & 1.0 \\
\hline UK & 122 & 20.5 & Canada & 5 & 0.8 \\
\hline Denmark & 61 & 10.3 & Hong Kong & 5 & 0.8 \\
\hline Australia & 58 & 9.8 & New Zealand & 5 & 0.8 \\
\hline Ireland & 50 & 8.4 & Malaysia & 4 & 0.7 \\
\hline Sweden & 34 & 5.7 & Switzerland & 4 & 0.7 \\
\hline Finland & 28 & 4.7 & Israel & 3 & 0.5 \\
\hline Norway & 22 & 3.7 & Jordan & 2 & 0.3 \\
\hline Spain & 20 & 3.4 & France & 1 & 0.2 \\
\hline Singapore & 13 & 2.2 & India & 1 & 0.2 \\
\hline Germany & 9 & 1.5 & Japan & 1 & 0.2 \\
\hline Italy & 8 & 1.3 & Saudi Arabia & 1 & 0.2 \\
\hline China & 7 & 1.2 & Slovenia & 1 & 0.2 \\
\hline Total & & & $\mathbf{5 9 4}$ & $\mathbf{1 0 0 . 0}$ \\
\hline
\end{tabular}

Table 9. Geographical Regions of Authors

\begin{tabular}{|l|c|c|}
\hline \multicolumn{1}{|c|}{ Association for Information Systems (AIS) Region } & Count & $\mathbf{\%}$ \\
\hline AIS-R2 - Europe \& UK & 366 & 61.6 \\
\hline AIS-R1 - USA \& Canada & 128 & 21.5 \\
\hline AIS-R3 - Australia \& New Zealand & 63 & 10.6 \\
\hline $\begin{array}{l}\text { AIS-R3 - South Korea, Singapore, Hong Kong, Taiwan, China, } \\
\text { Japan, India, Malaysia }\end{array}$ & 31 & 5.2 \\
\hline AIS-R2 - Middle East \& Africa & 6 & 1.0 \\
\hline Total & $\mathbf{5 9 4}$ & $\mathbf{1 0 0 . 0}$ \\
\hline
\end{tabular}




\subsection{Citation Analysis}

A citation analysis was conducted to determine the research impact of the most influential authors and studies based on the number of IFIP 8.6 publication citations.

Table 10. Most Cited Articles from IFIP WG8.6 Proceedings (Retrieved form Google Scholar on May 1, 2009)

\begin{tabular}{|c|c|c|}
\hline Study & \begin{tabular}{|c|} 
GS- \\
Citation
\end{tabular} & Article Title \\
\hline \multicolumn{3}{|c|}{ Pittsburgh, USA -1993 } \\
\hline Saga \& Zmud (1993) & 103 & $\begin{array}{l}\text { The Nature and Determinants of IT Acceptance, } \\
\text { Routinization, and Infusion }\end{array}$ \\
\hline $\begin{array}{l}\text { Fichman \& Kemerer } \\
\text { (1993) }\end{array}$ & 30 & $\begin{array}{l}\text { Toward a Theory of the Adoption and Diffusion } \\
\text { of Software Process Innovations }\end{array}$ \\
\hline \multicolumn{3}{|c|}{ Oslo, Norway - 1995} \\
\hline $\begin{array}{l}\text { Moore \& Benbasat } \\
\text { (1995) }\end{array}$ & 83 & $\begin{array}{l}\text { Integrating Diffusion of Innovations and Theory } \\
\text { of Reasoned Action Models to Predict Utilization } \\
\text { of Information Technology by End-Users }\end{array}$ \\
\hline Thong \& Yap (1995) & 28 & $\begin{array}{l}\text { Information Technology Adoption by Small } \\
\text { Business: An Empirical Study }\end{array}$ \\
\hline \multicolumn{3}{|c|}{ Ambleside, UK - 1997} \\
\hline McMaster et al. (1997) & 43 & Technology Transfer: Diffusion or Translation? \\
\hline $\begin{array}{l}\text { Buscher \& Mogensen } \\
\text { (1997) }\end{array}$ & 18 & $\begin{array}{l}\text { Mediating Change: Translation and Mediation in } \\
\text { the Context of Bricolage }\end{array}$ \\
\hline \multicolumn{3}{|c|}{ Helsinki, Finland - 1998} \\
\hline Schultze (1998) & 79 & $\begin{array}{l}\text { Investigating the Contradictions in Knowledge } \\
\text { Management }\end{array}$ \\
\hline Gasson (1998) & 28 & $\begin{array}{l}\text { A Social Action Model of Situated Information } \\
\text { Systems Design }\end{array}$ \\
\hline \multicolumn{3}{|c|}{ Bnaff, Canada - 2001} \\
\hline $\begin{array}{l}\text { Lyytinen \& Damsgaard } \\
\text { (2001) }\end{array}$ & 58 & $\begin{array}{l}\text { What's Wrong with the Diffusion of Innovation } \\
\text { Theory? }\end{array}$ \\
\hline $\begin{array}{l}\text { Pries-Heje \& Tyrde } \\
\text { (2001) }\end{array}$ & 14 & $\begin{array}{l}\text { Diffusion and Adoption of IT Products and } \\
\text { Processes in a Danish Bank }\end{array}$ \\
\hline \multicolumn{3}{|c|}{ Sydney, Australia - 2002} \\
\hline $\begin{array}{l}\text { Themistocleous \& Irani } \\
\text { (2002) }\end{array}$ & 10 & $\begin{array}{l}\text { A Model for Adopting Enterprise Application } \\
\text { Integration Technology }\end{array}$ \\
\hline $\begin{array}{l}\text { Serour \& Henderson- } \\
\text { Sellers (2002) }\end{array}$ & 8 & $\begin{array}{l}\text { Organizational Culture on the Adoption and } \\
\text { Diffusion of Software Engineering Process: an } \\
\text { Empirical }\end{array}$ \\
\hline \multicolumn{3}{|c|}{ Copenhagen, Denmark - 2003} \\
\hline $\begin{array}{l}\text { Boving \& Bodker } \\
\text { (2003) }\end{array}$ & 5 & $\begin{array}{l}\text { Where Is the Innovation? The Adoption of } \\
\text { Virtual Work Spaces }\end{array}$ \\
\hline Heikkila et al. (2003) & 5 & $\begin{array}{l}\text { Taking Organizational Implementation Seriously: } \\
\text { The Case of IOS Implementation }\end{array}$ \\
\hline
\end{tabular}


Table 10. (continued)

\begin{tabular}{|l|c|l|}
\hline \multicolumn{3}{|c|}{ Atlanta, USA - 2005 } \\
\hline $\begin{array}{l}\text { Abrahamsson et al. } \\
(2005)\end{array}$ & 4 & $\begin{array}{l}\text { Improving Business Agility Through Technical } \\
\text { Solutions: A Case Study on Test-Driven } \\
\text { Development in Mobile Software Development }\end{array}$ \\
\hline Dove (2005) & 4 & $\begin{array}{l}\text { Agile Enterprise Cornerstones: Knowledge, } \\
\text { Values, and Response Ability }\end{array}$ \\
\hline Levine (2005) & 4 & $\begin{array}{l}\text { Reflections on Software Agility and Agile } \\
\text { Methods: Challenges, Dilemmas, and the Way } \\
\text { Ahead }\end{array}$ \\
\hline $\begin{array}{l}\text { Helfert \& Duncan } \\
\text { (2006) }\end{array}$ & 4 & $\begin{array}{l}\text { Aspects on Information Systems Curriculum: A } \\
\text { Study Program in Business Informatics }\end{array}$ \\
\hline \multicolumn{3}{|c|}{ Manchester, UK - 2007 } \\
\hline Parsons et al. (2007) & 4 & $\begin{array}{l}\text { The Impact of Methods and Techniques on } \\
\text { Outcomes from Agile Software Development } \\
\text { Projects }\end{array}$ \\
\hline
\end{tabular}

Table 11. Total Citation Counts for Most Active Authors from IFIP WG8.6 Conferences (Retrieved form Google Scholar on May 1, 2009)

\begin{tabular}{|l|c|c|l|c|c|}
\hline \multicolumn{1}{|c|}{ Author } & $\begin{array}{c}\text { Citation } \\
\#\end{array}$ & $\begin{array}{c}\text { Avg } \\
\text { Citation }\end{array}$ & \multicolumn{1}{c|}{ Author } & $\begin{array}{c}\text { Citation } \\
\#\end{array}$ & $\begin{array}{c}\text { Avg } \\
\text { Citation }\end{array}$ \\
\hline Zmud, R. W. & 128 & 32.0 & Swanson, E. B. & 8 & 2.0 \\
\hline McMaster, T. & 92 & 9.2 & Henriksen, H. Z. & 7 & 1.8 \\
\hline Damsgaard, J. & 85 & 12.1 & Ginn, M. L. & 5 & 1.7 \\
\hline Lyytinen, K. & 82 & 11.7 & Sambamurthy, V. & 4 & 1.3 \\
\hline Wastell, D. G. & 74 & 8.2 & Sauer, C. & 4 & 1.3 \\
\hline Vidgen, R. T. & 71 & 23.7 & Costello, G. J. & 3 & 1.0 \\
\hline Pries-Heje, J. & 43 & 4.3 & Donnellan, B. & 3 & 1.0 \\
\hline Kautz, K. & 35 & 2.3 & Fowler, P. & 3 & 1.0 \\
\hline Fichman, R. G. & 30 & 10.0 & Borjesson, A. & 2 & 0.7 \\
\hline Baskerville, R. L. & 21 & 7.0 & Chiasson, M. W. & 2 & 0.7 \\
\hline Levine, L. & 18 & 2.3 & Dwivedi, Y. K. & 2 & 0.5 \\
\hline Fitzgerald, B. & 16 & 2.3 & Nielsen, P. A. & 2 & 0.5 \\
\hline Larsen, T. J. & 11 & 1.8 & Bunker, D. & 1 & 0.2 \\
\hline Mathiassen, L. & 11 & 1.8 & Finnegan, P. & 0 & 0.0 \\
\hline Leon, G. & 9 & 2.3 & Feller, J. & 0 & 0.0 \\
\hline
\end{tabular}

Citation data (citation count and article frequency) from Google Scholar was retrieved on May 1, 2009, for all 271 articles appearing in IFIP 8.6 proceedings between the years 1993 and 2008. A total of 19 studies with larger values of citation counts from 
Table 12. Most Frequently Utilized Keywords (Approach Adapted from Dwivedi, Lal et al. 2008; Dwivedi et al. 2009)

\begin{tabular}{|l|c|l|}
\hline Conference & \# of KW & \multicolumn{1}{|c|}{ Most Frequently Used KW } \\
\hline & & $\begin{array}{l}\text { Organizational Impacts (15); Technology Transfer (14); } \\
\text { Diffusion (14); Software Engineering (13); Adoption } \\
\text { (12); Information Systems (11); Actor-Network Theory } \\
\text { (11); Diffusion of Innovation(s) (10); Implementation } \\
\text { (10); Management of Computing and Information } \\
\text { Systems (10); Open Innovation (9); Innovation (9); } \\
\text { Software Process (9); Case Study (8); Project and People } \\
\text { Management (8); Action Research (7); Computer and } \\
\text { Society (7); Agility (6); Information Technology (6); } \\
\text { ICT (5); Institutional Theory (5); Design (4); Organiza- } \\
\text { tional Change (4); Technology Adoption (4); Tools and } \\
\text { Techniques (4); Translation (4); Software Development } \\
\text { (4); Organizational Resilience (4); Knowledge Manage- } \\
\text { ment (4); SMEs (4); Installation Management (3); Diffu- } \\
\text { sion Theory (3); ERP (3); IT Diffusion (3); Inter- } \\
\text { organizational Systems (3); E-Business (3); Information } \\
\text { Infrastructure (3); Grounded Theory (3); EDI (3); } \\
\text { Electronic Data Interchange (3); Resilience (3); Manage- } \\
\text { ment (3); Organization (3); Change Management (3) }\end{array}$ \\
\hline $\begin{array}{l}\text { Pittsburgh, } \\
\text { USA }\end{array}$ & 107 & $\begin{array}{l}\text { Organizational Impacts (15); Management of Computing } \\
\text { and Information Systems (10); Project and People Man- } \\
\text { agement (8); Software Engineering (8); Computer and } \\
\text { Society (7); Information Systems (5); Technology Trans- } \\
\text { fer (4); Tools and Techniques (4); Installation Manage- } \\
\text { ment (3) }\end{array}$ \\
\hline $\begin{array}{l}\text { Oslo, } \\
\text { Norway }\end{array}$ & 54 & $\begin{array}{l}\text { Implementation (3); Technology Transfer (3); Adoption } \\
\text { (2) }\end{array}$ \\
\hline $\begin{array}{l}\text { Ambleside, } \\
\text { UK }\end{array}$ & 111 & $\begin{array}{l}\text { Implementation (4); Innovation (4); Technology } \\
\text { Transfer (4); Diffusion (3); Actor-Network Theory (2); } \\
\text { Case Study (2); Diffusion Theory (2); Translation (2) }\end{array}$ \\
\hline Australia \\
Denmark
\end{tabular}


Table 12. (continued)

\begin{tabular}{|l|c|l|}
\hline $\begin{array}{l}\text { Atlanta, } \\
\text { USA }\end{array}$ & 62 & Agility (6); Software Process Improvement (3) \\
\hline $\begin{array}{l}\text { Galway, } \\
\text { Ireland }\end{array}$ & 97 & $\begin{array}{l}\text { Organizational Resilience (4); Resilience (3); Action } \\
\text { Research (2); Diffusion of Innovation (2) }\end{array}$ \\
\hline $\begin{array}{l}\text { Manchester, } \\
\text { UK }\end{array}$ & 139 & $\begin{array}{l}\text { Software Development (4); Actor-Network Theory (2); } \\
\text { Diffusion of Innovation (4); Case Study (3); Software } \\
\text { Process Improvement (2); SMEs (2); ICT (2); Work } \\
\text { Practices (2); Information Systems (2); RFID (2); Agile } \\
\text { Method (2) }\end{array}$ \\
\hline $\begin{array}{l}\text { Madrid, } \\
\text { Spain }\end{array}$ & 147 & $\begin{array}{l}\text { Open Innovation (9); Diffusion (4); Adoption (3); Value } \\
\text { Creation (2); ERP (2); Telecommunication (2); ICT (2); } \\
\text { Innovation (2); Institutional Theory (2) }\end{array}$ \\
\hline
\end{tabular}

each year are listed in Table 10, which includes the study with the largest countSaga and Zmud (1993)—with a citation count of 103, followed by Moore and Benbasat (1995), which has received 83 citations (see Table 10).

In terms of impact of researchers, with 128 citations Zmud emerged as a most-cited contributor to IFIP 8.6 conferences, followed by McMaster with 92 total citations. Damasgaard, Lyytinen, Wastell, and Vidgen have also received significant citation counts for their publications appearing in the IFIP 8.6 proceedings. Total citation counts and average citation counts (Total Citation Counts/Total Number of Papers) for most active authors are presented in Table 11. When average citation was considered, impact of the listed authors slightly differs. For example, McMaster was the second most-cited according to total citations but placed at seventh position if we consider average citation according to author.

\subsection{Keyword Analysis: Popular Keywords}

In order to assess the most frequently utilized (employed) keywords, all keywords were collected from 271 studies published in the IFIP 8.6 proceedings. These keywords were then sorted into alphabetical order to explore the most frequently utilized keywords. Table 12 presents the breakdown of the number of keywords from different conferences. A total of 959 keywords were extracted from the 271 articles, including 45 keywords that were used three or more times. These 45 keywords, along with their frequency, are listed in Table 12. Organizational impact was the most frequently used keyword, with 15 papers utilizing it, followed by technology transfer and diffusion, each represented by 14 articles. Software engineering emerged as the third most utilized keyword, with 13 studies using this keyword. This was closely followed by adoption (12), information systems (11), actor-network theory (11), and diffusion of innovation(s) (10). Table 12 summarizes the frequency of usage of the 45 most frequently utilized keywords. The table also presents the most frequently utilized keywords and their frequency from each conference. The trend of keyword utilization suggests that IFIP 8.6 is the leading forum for presentation and publication of timely and relevant research in the domain of adoption and diffusion of IT/IS as a large number of topics were investigated in the previous IFIP 8.6 conferences 
(Table 12). The keyword list presented in the table shows that research published in IFIP 8.6 has evolved from basic issues (such as examining the organizational impacts, tools, and techniques) to issues pertaining to contemporary themes such as open innovation. The keyword list also shows that the dominant theoretical perspectives popular among the researchers in this community include diffusion of innovation, actor- network theory, and institutional theory, while the most popular methods include case study and action research.

\section{Conclusions}

The aim of this paper was to contribute to a greater understanding of the evolution of the activities of the IFIP WG 8.6 research community by presenting the results of an analysis of the 271 articles that appeared in the conference proceedings between the years 1993 and 2008. The paper presented the results of an investigation along a series of demographic dimensions including most active authors, research impact of most active authors, authors' backgrounds, universities, country, region, and most frequently used keywords. The following are the summary key points that have emerged from the analysis presented in the paper:

- In terms of most active authors, one author was a clear distance ahead of the rest with 15 publications in total.

- $\quad$ Authors were predominantly male.

- A large proportion of IFIP WG 8.6 authors hold professorships, followed by practitioners and lecturers.

- Although IFIP WG 8.6 authorship includes a large proportion of industry experts, their numbers are significantly lower than academic contributors. This suggests that there is further scope for involving contributors from industry in order to make the conference more relevant and interesting.

- IFIP 8.6 articles illustrated a high level of collaborative work, both among academic authors and between academic and industry experts.

- The university with the largest number of contributors (31) is the Copenhagen Business School in Denmark. The top 30 list also includes a number of universities from the United States, the United Kingdom, Singapore, Hong Kong, and Australia, and number of European countries.

- It is also interesting to note that a commercial Organization (Ericsson AB) appeared within the list of most active institutions.

- The United States closely followed by the United Kingdom are the largest contributors of IFIP 8.6 authors and institutions. Consequently, a portion of AIS Region 2 (Europe and the United Kingdom) emerged as the most dominant region, followed by a portion of AIS Region 1 (United States and Canada).

- The highest research impact is reported for the paper by Saga and Zmud (1993), followed by Moore and Benbasat (1993), determined by citations obtained from Google Scholar for all articles published in IFIP 8.6 proceedings.

- In terms of individual author, the highest research impact is reported for Zmud, followed by McMaster, again determined by citations obtained from Google Scholar for all articles by a particular author published in IFIP 8.6 proceedings. 
- A keywords analysis indicated that organizational impact, technology transfer, diffusion, software engineering, and adoption were the most utilized keywords, or in other words, the most investigated research issues.

- Actor-network theory, diffusion of innovation, and institutional theory are the most frequently utilized keywords that relate to theoretical perspectives in IFIP 8.6 publications. Action research and case study form examples of the most frequently utilized methodological keywords.

\subsection{Future Research Implications}

The results obtained can be utilized as input to a number of further analyses along different lines. For instance, the authors intend to conduct additional content analysis of IFIP WG 8.6 proceedings in order to examine variables such as units of analysis, research methods, and analysis techniques employed, and hence contribute to an understanding of past and current methodological and theoretical practices within the research community. This will reveal the level of diversity, and provide an indication to whether there is a need to promote and encourage greater diversity in IFIP WG 8.6 research. Second, the authors intend to carry out an analysis along the lines of social network analysis in order to illustrate the evolution of the IFIP WG 8.6 research community. Finally, more extensive work on keywords analysis would be valuable. This would potentially illustrate the changing perspectives and trends in the focus of IFIP WG 8.6, and could also involve the creation of a classification scheme to group existing keywords in different categories so that future archival analysis would be able to identify topics that have become less relevant over time, and those that have emerged since the establishment of the classification scheme.

\section{References}

Avison, D., Dwivedi, Y.K., Fitzgerald, G., Powell, P.: The Beginnings of a New Era: Time to Reflect on 17 Years of the ISJ. Information Systems Journal 18(1), 5-21 (2008)

Dwivedi, Y.K., Kiang, M., Lal, B., Williams, M.D.: Profiling Research Published in the Journal of Electronic Commerce Research. Journal of Electronic Commerce Research 9(2), 77-91 (2008)

Dwivedi, Y.K., Kuljis, J.: Profile of IS Research Published in the European Journal of Information Systems. European Journal of Information Systems 17(6), 678-693 (2008)

Dwivedi, Y.K., Lal, B., Mustafi, N., Williams, M.D.: Profiling IS Research Published in the Information Systems Frontiers. Information Systems Frontiers 11(1), 87-102 (2009)

Dwivedi, Y.K., Williams, M.D., Lal, B.: The Diffusion of Research on the Adoption \& Diffusion of Information Technology. In: León, G., Bernardos, A., Casar, J., Kautz, K., DeGross, J.I. (eds.) Open IT-Based Innovation: Moving Towards Cooperative IT Transfer and Knowledge Diffusion, pp. 3-22. Springer, Boston (2008)

Levine, L. (ed.): Diffusion, Transfer, \& Implementation of Information Technology. NorthHolland, Amsterdam (1994)

Moore, G.C., Benbasat, I.: Integrating Diffusion of Innovations and Theory of Reasoned Action Models to Predict Utilization of Information Technology by End-Users. In: Pries-Heje, J., Kautz, K. (eds.) Business Agility and Information Technology Diffusion, pp. 132-146. Chapman \& Hall, London (1995) 
Palvia, P., Pinjani, P., Sibley, E.H.: A Profile of Information Systems Research Published in the Information \& Management. Information \& Management 44, 1-11 (2007)

Saga, V.L., Zmud, R.W.: The Nature and Determinants of IT Acceptance, Routinization, and Infusion. In: Levine, L. (ed.) Diffusion, Transfer and Implementation of Information Technology, pp. 67-86. North-Holland, Amsterdam (1993)

Whitley, E.A., Galliers, R.D.: An Alternative Perspective on Citation Classics: Evidence from the First 10 Years of the European Conference on Information Systems. Information \& Management 44(5), 441-455 (2007)

Williams, M.D., Dwivedi, Y.K., Lal, B., Schwarz, A.: Contemporary Trends and Issues in IT Adoption and Diffusion Research. Journal of Information Technology 24(1), 1-10 (2009)

\section{About the Authors}

Yogesh K. Dwivedi is a senior lecturer in Information Systems at the School of Business and Economics, Swansea University, Wales, UK. He obtained his Ph.D. and M.Sc. in Information Systems from Brunel University, UK. He has coauthored several papers which have appeared in international referred journals such as Communications of the ACM, DATA BASE, European Journal of Information Systems, Information Systems Journal, Information Systems Frontiers, Journal of Computer Information Systems, Journal of Information Technology, Journal of the Operational Research Society, and Industrial Management \& Data Systems. He is a senior editor of DATA BASE, an assistant editor of Transforming Government: People, Process and Policy, and managing editor of Journal of Electronic Commerce Research, and a member of the editorial and review boards of several journals. He is also a member of the Association for Information Systems and IFIP WG8.6. He can be reached at ykdwivedi@gmail.com.

Linda Levine is a senior member of the technical staff at Carnegie Mellon University's Software Engineering Institute. Her research focuses on acquisition of software intensive systems, agile software development, system of systems interoperability, diffusion of innovations, and knowledge integration and transfer. She holds a Ph.D. in Rhetoric from Carnegie Mellon University. She is a member of the Association for Information Systems, IEEE Computer Society, National Communication Association, and is a cofounder and chair of IFIP Working Group 8.6 on Diffusion, Transfer and Implementation of Information Technology. Contact her at $11 @$ sei.cmu.edu.

Michael D. Williams is a professor in the School of Business and Economics at Swansea University in the UK. He holds a B.Sc. from the CNAA, an M.Ed. from the University of Cambridge, and a Ph.D. from the University of Sheffield. He is a member of the British Computer Society and is registered as a Chartered Engineer. Prior to entering academia, Professor Williams spent 12 years developing and implementing ICT systems in both public and private sectors in a variety of domains including finance, telecommunications, manufacturing, and local government, and since entering academia, has acted as a consultant for both public and private organizations. He is the author of numerous fully refereed and invited papers within the ICT domain, has editorial board membership with a number of academic journals, 
and has obtained external research funding from sources including the European Union, the Nuffield Foundation, and the Welsh Assembly Government. He can be reached at m.d.williams@swansea.ac.uk.

Mohini Singh is a professor of Information Systems at the School of Business Information Technology at RMIT University in Australia. She earned her Ph.D. from Monash University and has published widely in the areas of e-business and new technology and innovation management. Her publications comprise books, book chapters, journal articles, and conference papers. She serves as a member on the editorial boards of a number of journals and co-chairs tracks on e-government and IT diffusion at a number of international conferences. The focus of her current research is on the diffusion of Web 2.0 technologies in business organizations, mobile technologies, and e-government. She can be contacted at mohini.singh@rmit.edu.au.

David Wastell is a professor of Information Systems at Nottingham University Business School. He began his research career as a psycho-physiologist before moving into information systems. His research interests are in public sector reform, innovation and design, management epistemology, and cognitive ergonomics. He has co-organized two previous IFIP WG8.6 conferences (1997 and 2007) and was research co-chair for the IFIP WG8.2 conference in Manchester in 2004. David may be contacted at david.wastell@nottingham.ac.uk.

Deborah Bunker is a senior lecturer in the Business Information Systems discipline at the University of Sydney having previously held senior academic and administrative positions at the University of New South Wales and University of Wollongong. Her research interests are in IS philosophy, IS management, IS diffusion, and ecommerce/e-business. She is also president of the Australasian Association of IS and vice chair of IFIP WG 8.6, Diffusion, Transfer, and Implementation of Information Technology. Deborah can be reached at D.Bunker@econ.usyd.edu.au. 